\title{
Exuberant case of erythema annulare centrifugum
}

\author{
Sónia Raquel Mendes, Ana Rita Gameiro, José Carlos Cardoso, Hugo Oliveira
}

Dermatology Department, Coimbra University Hospital, Coimbra, Portugal

\section{Correspondence to} Dr Sónia Raquel Mendes; soniaraquel23@gmail.com

Accepted 4 June 2021
Check for updates

(c) BMJ Publishing Group Limited 2021. No commercial re-use. See rights and permissions. Published by BMJ.

\begin{tabular}{l} 
To cite: Mendes SR, \\
Gameiro AR, Cardoso JC, \\
et al. BMJ Case Rep \\
2021;14:e243431. \\
doi:10.1136/bcr-2021- \\
243431 \\
\hline
\end{tabular}

\section{DESCRIPTION}

The authors describe the case of a 63-year-old female patient with a history of left mastectomy due to breast adenocarcinoma at the age of 45 years and a neuroendocrine tumour of the terminal ileum diagnosed 3 months before the appearance of diffuse skin lesions.

Her medical history also included dyslipidaemia, high blood pressure and type 2 diabetes mellitus.

The patient had no history of previous infectious diseases, trauma in the past months or any recently started medicines.

The skin lesions were annular-shaped with an erythematous border and a diameter of about $3-4 \mathrm{~cm}$; they were scattered over the arms (figure 1), thighs and abdomen. The clinical onset was sudden, the lesions developed over a week and were associated with pruritus.

A skin biopsy revealed a tightly cuffed perivascular infiltrate in the superficial dermis, associated with mild epidermal spongiosis and focal exocytoses of lymphocytes, consistent with the superficial variant of erythema annulare centrifugum (EAC) (figure 2).

Laboratory workup ruled out conditions like hypothyroidism or connective tissue diseases that could mimic EAC.

Initially, the patient was treated with a topical corticosteroid daily for 1 month, which significantly improved the pruritus.

Concurrently, liver metastases of the ileal neuroendocrine tumour were diagnosed and an immunosuppressant drug, mTOR (mechanistic target of rapamycin) inhibitor everolimus, was started.

The skin lesions become less noticeable and topical corticosteroid was only applied if pruritus occurred.

After 1 year, the lesions disappeared completely and there were no signs of recurrence or other skin lesions during 4 years of follow-up.

EAC, which was first described in 1916 by Darier, is a rare dermatosis of unknown aetiology with no known predilection for sex or age. ${ }^{1-4}$ It can be classified histopathologically into superficial and deep types. ${ }^{1-3}$ EAC has been associated with infections, particularly with dermatophytes, drugs, tumours and haematological diseases. ${ }^{12}$ However, in most cases, a relationship with a triggering agent is not found. ${ }^{2}$ The typical presentation of EAC consists of erythematous papules that grow centrifugally and clear in the centre, giving rise to annular plaques with an elevated border and characteristic trailing scale at their inner slope. ${ }^{1-4}$ The diameter is variable and the lesions may be pruritic. ${ }^{2}$ There is a predilection for the trunk and lower limbs, usually sparing the palms and soles; individual lesions can last from weeks to months, but the disease can evolve during

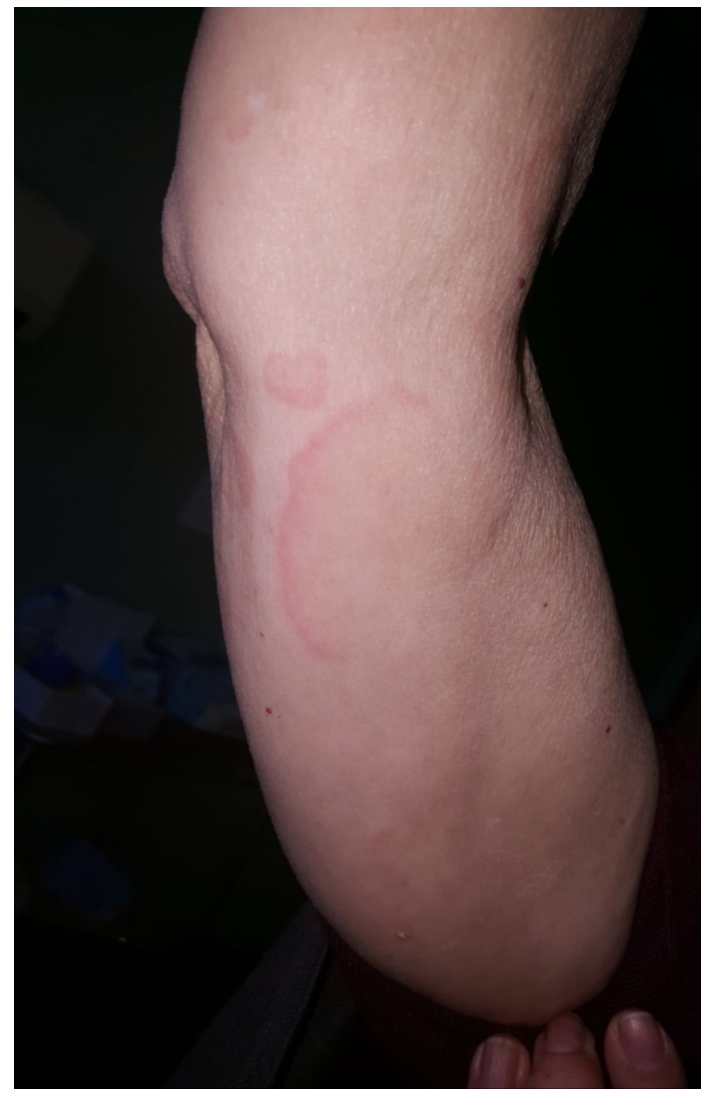

Figure 1 Annular lesions with erythematous border in the right arm, the biggest lesion $4 \mathrm{~cm}$ wide.

decades. ${ }^{2}$ When a causative factor is identified, its eviction or correction may lead to remission of the lesions. ${ }^{2}{ }^{4}$ There is no specific treatment, and topical corticosteroids may be useful for treating the lesions, particularly in patients who report

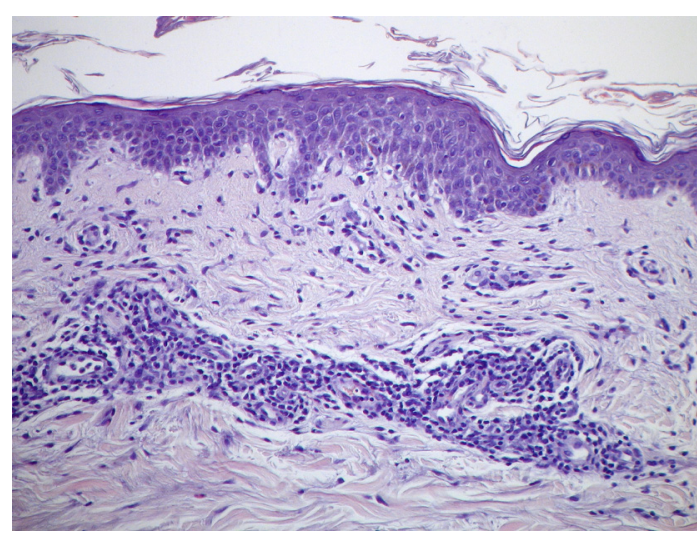

Figure 2 Tightly cuffed perivascular infiltrate, the socalled 'coat sleeve' appearance in the superficial dermis (H\&E 100x). 
pruritus. ${ }^{24}$ Antibacterial or antifungal therapies have also been used, with variable results. ${ }^{2}$

This case aims to emphasise the association of EAC with malignancy, specifically with the neuroendocrine tumour of the terminal ileum with liver metastases. Fortunately, in our patient, the oncological disease is stable and she has been kept on imunossupressive therapy. These two relevant elements may be the reason for no recurrence of the EAC.

\section{Learning points}

The diagnosis of erythema annulare centrifugum (EAC) is mainly clinical, although a cutaneous biopsy may be necessary to confirm it and exclude other diagnoses.

- The prognosis is excellent, as EAC tends to regress irrespective of the therapeutic option used, unless there is underlying malignancy or other associated non-controllable systemic disease.
Contributors SRM (first author): acquisition and analysis of data, planning, conducting, conception and design of the article, as well as revision and final approval. ARG: acquisition of data, revision and final approval. JCC: acquisition of data, revision and final approval. HO: acquisition of data, revision and final approval.

Funding The authors have not declared a specific grant for this research from any funding agency in the public, commercial or not-for-profit sectors.

Competing interests None declared.

Patient consent for publication Obtained.

Provenance and peer review Not commissioned; externally peer-reviewed.

\section{REFERENCES}

1 Kim DH, Lee JH, Lee JY, et al. Erythema annulare centrifugum: analysis of associated diseases and clinical outcomes according to histopathologic classification. Ann Dermatol 2016:28:257-9.

2 Kim KJ, Chang SE, Choi JH, et al. Clinicopathologic analysis of 66 cases of erythema annulare centrifugum. J Dermatol 2002;29:61-7.

3 Weyers W, Diaz-Cascajo C, Weyers I. Erythema annulare centrifugum: results of a clinicopathologic study of 73 patients. Am J Dermatopathol 2003:25:451-62.

4 Minni J, Sarro R. A novel therapeutic approach to erythema annulare centrifugum. J Am Acad Dermatol 2006:54:S134-5.

Copyright 2021 BMJ Publishing Group. All rights reserved. For permission to reuse any of this content visit

https://www.bmj.com/company/products-services/rights-and-licensing/permissions/

BMJ Case Report Fellows may re-use this article for personal use and teaching without any further permission.

Become a Fellow of BMJ Case Reports today and you can:

- Submit as many cases as you like

- Enjoy fast sympathetic peer review and rapid publication of accepted articles

- Access all the published articles

Re-use any of the published material for personal use and teaching without further permission

Customer Service

If you have any further queries about your subscription, please contact our customer services team on +44 (0) 2071111105 or via email at support@bmj.com.

Visit casereports.bmj.com for more articles like this and to become a Fellow 